\title{
Distribution and abundance of minipellets around the Antarctic peninsula. Implications for protistan feeding behaviour
}

\author{
Humberto E. González \\ Alfred Wegener Institute for Polar and Marine Research, Postfach 120161, W-2850 Bremerhaven, Germany
}

\begin{abstract}
During the 'European Polarstern Study' (EPOS) in the Scotia and Weddell Seas (SWS) and the XXVI Antarctic Chilean Expedition (INACH) in the South Shetland Islands area (SSIA), water and net samples were collected to assess the distribution, abundance, and role of minipellets in Antarctic waters. Two groups of minipellet producers, phaeodarian radiolarians and unarmoured dinoflagellates, were identified. The vertical (from surface to $100 \mathrm{~m}$ depth) distribution patterns of minipellets (5 to $100 \mu \mathrm{m}$ ) showed that the maximum concentration was located mainly between surface and $50 \mathrm{~m}$ depth in both the SWS and SSIA. On average, higher numbers of minipellets were found in the SWS $\left(814 \mathrm{l}^{-1}\right)$ than in the SSIA $\left(164 \mathrm{I}^{-1}\right)$. The most frequent and abundant silicified food items found in minipellets were diatom frustules. In phaeodarian radiolarians, the presence of partially ingested undamaged diatoms indicated that, in addition to feeding on detritus, phaeodarians also directly feed on phytoplankton. In both areas, higher numbers of minipellets occurred when the larger phytoplankton $(>25 \mu \mathrm{m})$ dominated the phytoplankton assemblage. Similarities between the diatom species composition in the water column and enclosed in minipellets suggest that grazing was non-selective.
\end{abstract}

\section{INTRODUCTION}

In the Southern Ocean the abundance of small faecal pellets in the water column can be as high as $214 \mathrm{l}^{-1}$ and they contribute up to $36 \%$ to the total volume of faeces collected in traps in the Weddell Sea (Nöthig \& Bodungen 1989). Protozoans, largely radiolarians and flagellates, have been mentioned as potential producers of minipellets in Antarctic waters (Gowing \& Coale 1988, Nöthig \& Bodungen 1989, Buck et al. 1990). However, the grazing impact of these protozoans on phytoplankton assemblages, as well as the origin, production and fate of their minipellets is poorly known (Garrison \& Gowing in press).

Recent enclosure experiments conducted with Scotia and Weddell Seas water (Bjørnsen \& Kuparinen 1991) and field observations in coastal areas of the Antarctic Peninsula (F. Brandini pers. comm.) demonstrated that grazing exerted by dinoflagellates can be significant in limiting phytoplankton biomass. Hence the production of minipellets can well be of ecological importance in the Southern Ocean. Different feeding mechanisms reported among heterotrophic dinoflagellates include: (1) direct engulfment in unarmoured genera; (2) envelopment of prey with a pseudopodium ('pallium') protruded through the flagellar pore (mainly in armoured genera); (3) sucking out of the prey contents with a feeding tube (Jacobson \& Anderson 1986, Gaines \& Elbrächter 1987, Hansen 1991a, b, 1992, Schnepf \& Elbrächter 1992). The production of minipellets has only been documented in relation to one of these feeding mechanisms: engulfment, and in some genera of unarmoured dinoflagellates (i.e. Nematodinium, Torodinium, Gymnodinium) (Buck et al. 1990, Elbrächter 1991). Thus, the in situ estimation of minipellet abundance obviously greatly underestimates the grazing impact exerted by protistans. However, it can give important insights into in situ food preferences and size-selectivity.

The ecological role of radiolarians has received little attention; although by feeding on a wide size-range of particles and producing a large quantity of minipellets (Gowing \& Coale 1988, Gowing 1989) their impact on pelagic systems is likely to be significant. 
The objectives of this study were to assess the minipellet abundance and distribution in the area around the South Shetland Islands (SSIA) and the Scotia and Weddell Seas (SWS) of the Antarctic Ocean at the tip of the Antarctic Peninsula and to identify some of the minipellet producers. The diatom taxa within minipellets were identified. In addition, information on protozoan and minipellet abundance was utilized to investigate both the potential particle selectivity and the grazing pressure exerted by the minipellet producers.

\section{MATERIALS AND METHODS}

Samples were collected during 2 cruises: (1) The 'European Polarstern Study' (EPOS) on board RV 'Polarstern' (22 November 1988 to 6 January 1989) in the SWS (Hempel et al. 1989). During EPOS Leg II, a multidisciplinary study of the pelagic system was carried out in 4 transects between 57 and $62^{\circ} \mathrm{S}, 3$ along the $49^{\circ} \mathrm{W}$ meridian and 1 along $47^{\circ} \mathrm{W}$ (Fig. 1). (2) The XXVI Antarctic Chilean Expedition (INACH) on board RV 'Capitán Alcazar' (7 to 27 February 1990) in the Bransfield Strait and Drake Passage area (Fig. 1). The total study area was divided into 3 sub-areas designated as (i) Drake Passage: Stns 5, 7, 8 \& 15, with greater influence of the Drake Passage; (ii) Bransfield Strait: Stns 2, 3, 22 \& 27, with greater influence of the Weddell Sea; and (iii) 'coastal-front': Stns $18 \& 20$, in the Bellingshausen-Weddell Sea front laccording to Amos 1987), and Stns 26 \& 31 in embayments.

From both the EPOS and INACH expeditions, water samples $(250 \mathrm{ml})$ were collected from the upper $100 \mathrm{~m}$ of the water column, using a General Oceanic rosette sampler with 12 l Niskin bottles. Samples were pre-

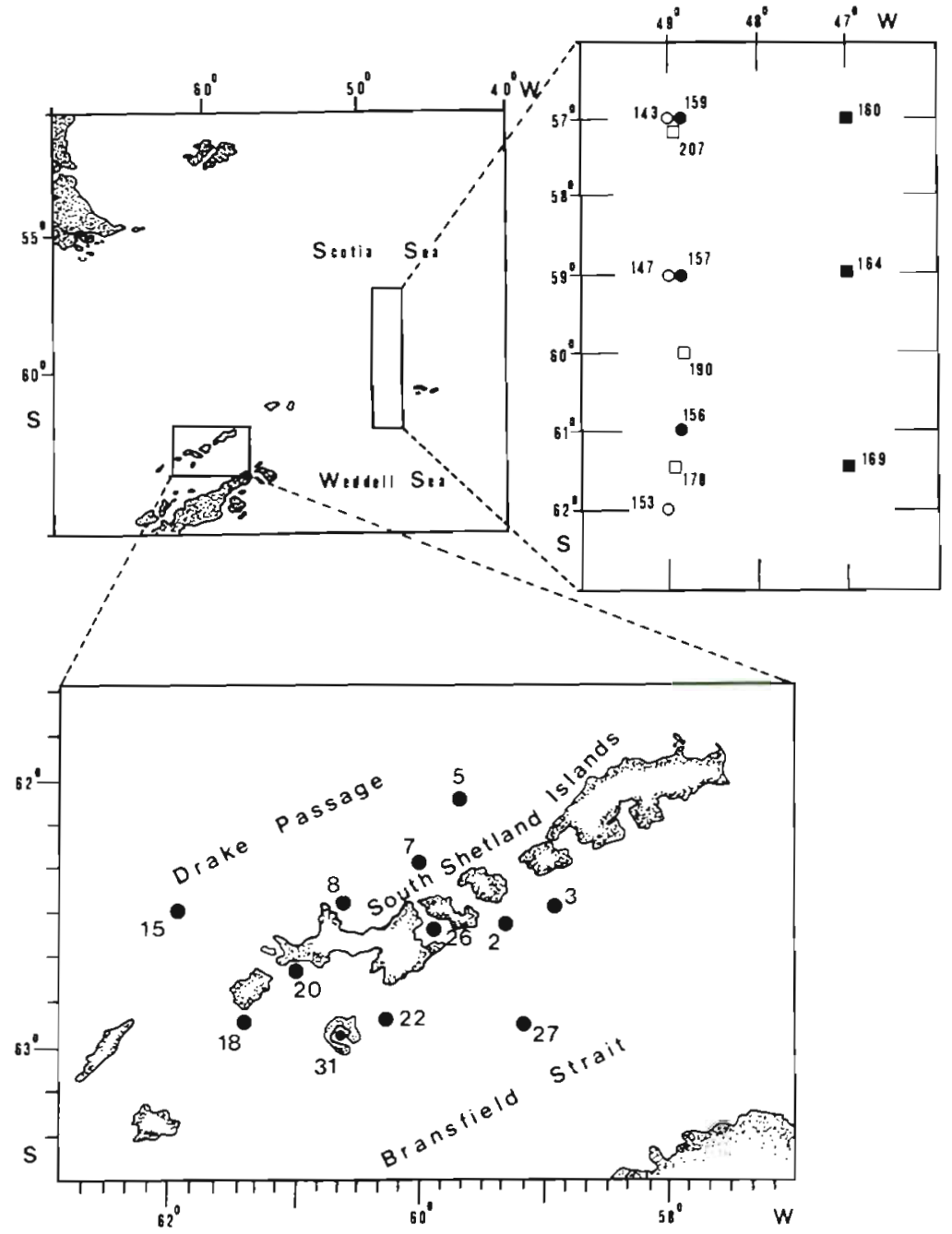

Fig. 1 Maps showing the EPOS (SWS: upper right) and INACH (SSIA: bottom) study arnas. Different symbols in the SWS map represent the 3 transects along the $49^{\circ} \mathrm{W}$ meridian and the transect along the $47^{\circ} \mathrm{W}$ meridian served in hexamine-buffered formalin (1.5\% final concentration). Minipellets as well as dominant phytoplankton species were counted and sized in $100 \mathrm{ml}$ settling chambers according to Utermöhl (1958), in the same samples, minipellets contents (mainly diatoms) were also analysed. In the SWS only total armoured dinoflagellates were counted and the number of heterotrophic individuals were estimated from the ratio between heterotrophic to total armoured dinoflagellates. This ratio was recorded from 40 samples collected at different stations of the SWS which were re-counted using an epifluorescent inverted microscope (see Table 3). Selected samples (with high minipellet abundance) were stained with the fluorochrome DAPI (Porter \& Feig 1980) to distinguish the faeces from possible faeces-like producers, i.e. skeleton-less phaeodarians, unarmoured dinoflagellates (Gowing \& Coale 1989). In addition to rosette samples minipellets as well as protozooplankton (i.e. radiolarians, tintinnids) were collected for qualitative analysis (faecal pellet contents) using a conical net $(50 \mu \mathrm{m}$ mesh size), hauled vertically from the upper $300 \mathrm{~m}$ of the water column. Phaeodarian radiolarians were counted from 10 samples collected in the upper $1000 \mathrm{~m}$ water column at 2 stations of the Weddell Sea during April-May 1992. All samples were preserved in formalin ( $2 \%$ final concentration) and analysed using light microscopy and scanning electron microscopy (SEM) (for 
details see González 1992). In order to assess the diatom species composition in the water column, additional samples were collected from the upper $100 \mathrm{~m}$ depth using a $20 \mu \mathrm{m}$ mesh-size net and treated for the removal of organic matter from diatom frustules according to the method of Hasle \& Fryxell (1970).

Diatoms and radiolarians were identified using the following taxonomical literature: Popofsky (1908), Schröder (1912), Hasle (1964, 1965a, b), Morley \& Stepien (1985), Priddle \& Fryxell (1985), Medlin \& Priddle (1990).

During the INACH cruise, additional water samples were collected to determine the size-fractionated chlorophyll a (chl a) biomass and processed according to González et al. (1989). Categories of picoplankton, nanoplankton and net-phytoplankton were assigned to the size fractions corresponding to $<1.8,1.8-25$ and $>25 \mu \mathrm{m}$, respectively. Statistical analysis was carried out on raw data using non-parametric tests: KruskalWallis analysis of variance $(H)$ and Spearman rank correlation ( $\mathrm{r}$ ) (Zar 1984).

The faecal material was defined as minipellets (Gowing \& Silver 1985) of probable protistan origin according to the following criteria: (1) The shape was usually round or slightly elongated, occasionally distorted due to the presence of big diatom frustules enclosed (see Figs. 4g, 6A, C). (2) The size range was generally between 5 and $120 \mu \mathrm{m}$ length. Larger sizes than the 5 to $50 \mu \mathrm{m}$ reported by Gowing \& Silver (1985) were found in water samples, as well as inside unarmoured dinoflagellates (e.g. see Fig. 6E: this Nitzschia sp. chain was $80 \mu \mathrm{m}$ in length). (3) A delicate boundary around intact diatom frustules was found, some of which still contained remains of protoplasm (see Fig. 6B, arrows), suggesting interrupted or incomplete digestion.

Numerous unarmoured dinoflagellates and phaeodarian radiolarians containing diatom frustules or with partly released minipellets were observed - and assumed to be producers of minipellets - in the 2 areas studied. The characteristics (size, color, shape, matrix, membrane, fluorescence) of these minipellets were also considered in the identification of minipellets from the water samples.

\section{RESULTS}

\section{Scotia \& Weddell Seas}

During the first $49^{\circ} \mathrm{W}$ transect - from end of November to beginning of December 1988 - the northern edge of the pack ice lay along the middle of the Confluence (ca $59^{\circ} 30^{\prime} \mathrm{S}$ ); northward transport of ice combined with ice melt resulted in slow southward retreat of the ice edge during the investigation period. During the last transect - January 1989 - the ice edge was located at $61^{\circ} \mathrm{S}$ in the Weddell Sea.

High numbers of minipellets were generally found in the upper $40 \mathrm{~m}$ (Fig. 2). The average minipellet abundance in the upper $100 \mathrm{~m}$ was $814 \mathrm{l}^{-1}(\mathrm{n}=45, \mathrm{SD}=$ 1977), however; when Stn 207 (in which a patch with high concentration was found) is not considered, the average abundance reduces to 437 minipellets $~^{-1}$ ( $\mathrm{n}=$ $42, \mathrm{SD}=668$ ). The results indicate the highly patchy distribution of minipellets.

Along the $49^{\circ} \mathrm{W}$ transects, integrated abundances of minipellets $\left(10^{6} \mathrm{~m}^{-2}\right.$, over the upper $100 \mathrm{~m}$ water column) were up to 2 orders of magnitude higher in the Scotia Sea $\left(57^{\circ} \mathrm{S}\right)$ and Weddell-Scotia Confluence (WSC; ca $59^{\circ} \mathrm{S}$ ) than at ice-covered stations (ca $61^{\circ}$ $30^{\prime} \mathrm{S}$ ). However, along the $47^{\circ} \mathrm{W}$ transect, minipellet abundance was higher at the ice-covered station (Stn 169) than in ice-free waters (Fig. 3).

Different species of radiolarians were found in the net samples along the 47 and $49^{\circ} \mathrm{W}$ transects. Qualitative

Minipellets $\mathrm{I}^{-1}$
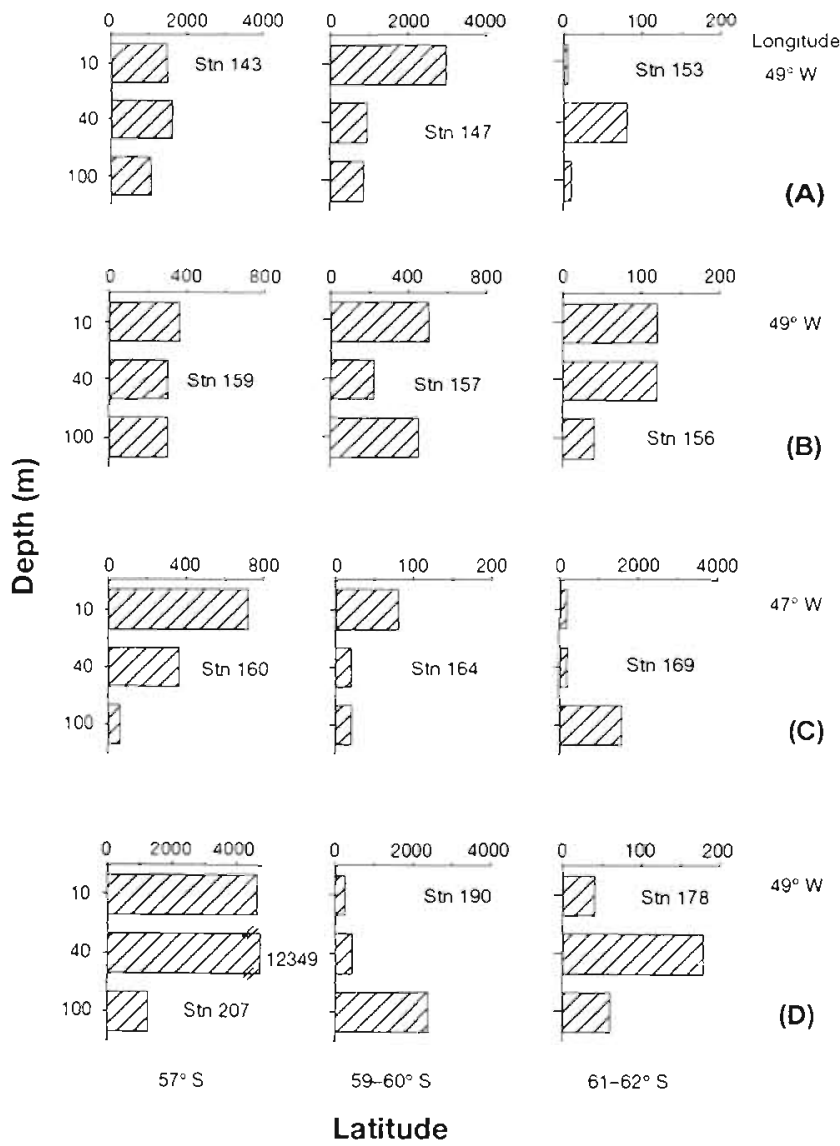

Fig. 2. Vertical distribution of minipellet abundance (no. of minipellets $1^{-1}$ ) in the SWS during: (A) the first $49^{\circ} \mathrm{W}$ transect; (B) the second $49^{\circ} \mathrm{W}$ transect; (C) the $47^{\circ} \mathrm{W}$ transect; and (D) the third $49^{\circ} \mathrm{W}$ transect. Note different scales of $x$-axis 


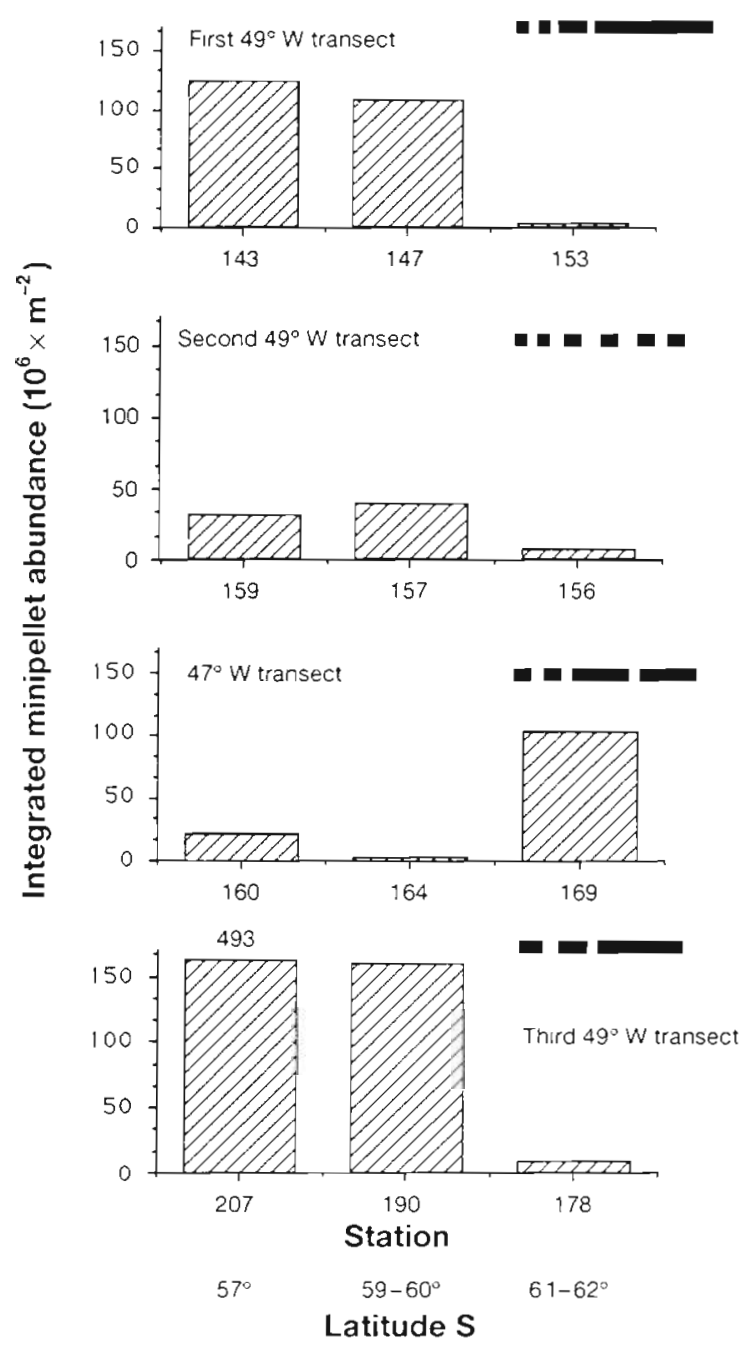

Fig. 3. Minipellet abundances $\left(10^{6} \times \mathrm{m}^{-2}\right)$ integrated over the upper $100 \mathrm{~m}$ water column. Horizontal solid bars represent the extent of ice cover

analysis showed high numbers of radiolarians at stations in the Scotia Sea (Stns $190 \& 207$ ) and in 1 ice-covered station (Stn 169). These stations roughly coincided with the stations with a maximum in minipellet abundance below $40 \mathrm{~m}$ depth. (Fig. 2). The most abundant Phaeodarian taxon at these stations was the Protocystis tridens/acornis complex Haeckel (Fig. 4e to g). P. harstoni Murray (Fig. 4b, i), P. micropelecus Haecker (Fig. 4d),
Challengeron swirei Murray (Fig 4a), C. bicorne Haecker, Aulographonium anthoides Haeckel, Cannosphaera antarctica Haeckel, Phaeodina antarctica Schröder (Fig. 4c), and Euphysetta sp. were also frequently found. Small numbers of Acantharia, Heliozoa (Sticholonche) and polycystine radiolarians were observed, but not further identified

Individual specimens of Protocystis tridens/acornis (36), P. harstoni (9) and P. micropelecus (7) from Stns 207, 169 \& 190 were examined using light microscopy and SEM. The phaeodia contained minipellets comprising mainly diatom fragments, but also whole frustules were observed in a few individuals. The more frequent diatom genera found in phaeodarian minipellets were Nitzschia $[N$. kerguelensis (Fig. 4f), N. rhombica, N. curta, and Nitzschia spp.], Thalassiosira [ $T$. antarctica/gravida and Thalassiosira spp. (Fig. 4i)\}, and frustules of Corethron criophilum (Fig. 4e). Individuals of $P$. antarctica (10) were observed with agglutinated siliceous skeletons of diatoms (Thalassiosira sp., Asteromphalus sp.), silicoflagellates (Distephanus speculum) and dinoflagellates (internal skeletons of Actiniscus sp.) (see Fig. 4c).

A total of 3556 minipellets from water samples collected at the 12 SWS stations were examined and the siliceous-skeleton food content determined. Many of them contained diatoms, mainly of the genera Nitzschia and Thalassiosira (Table 1). Minipellets with unidentifiable contents contributed $32.1 \%$ to the total count.

\section{South Shetland Islands area}

The South Shetland Islands area was not icecovered. The average abundance of minipellets was $164 \mathrm{l}^{-1}(\mathrm{SD}=187, \mathrm{n}=25)$, with a range of 0 to 860 (Fig. 5). No significant differences in abundance between 1,30 and $50 \mathrm{~m}$ depths were found $(179,185$ and $229 \mathrm{l}^{-1}$ respectively), but these values were significantly higher than those recorded from $100 \mathrm{~m}$ depth $\left(401^{-1}\right)(H=12.318, p<0.005)$. Integrated abundances of minipellets in the Drake Passage $\left(X=7.46 \times 10^{6} \mathrm{~m}^{-2}\right.$, $100 \mathrm{~m}$ water column) were similar to those in the Bransfield Strait $\left(X=10.3 \times 10^{6} \mathrm{~m}^{-2}\right)$ and significantly lower than those at the 'coastal-front' stations $(X=35.8$ $\left.\times 10^{6} \mathrm{~m}^{-2}\right)(H=10.31, \mathrm{p}<0.01)$.

Fig. 4. Common radiolarians found in the Scotia-Weddell Seas from net and water samples collected at Stns 157,190 \& 207. (a) Challengeron swirei; (b) Protocystis harstoni; (c) Phaeodina antarctica (note diatom frustules of Thalassiosira sp. and Asteromphalus sp. as well as silicoflagellate skeletons agglutinated): (d) Protocystis micropelecus. Individuals of Protocystis tridens/acornis complex ingested whole frustules of (e) Corethron criophilum and (f) Nitzschia kerguelensis. Individuals from this taxa were observed (g) with partly released minipellets or (h) in round, phaeodarian-like faeces. (i) Skeleton of $P$. harstoni, partially dissolved, containing nucleus and vacuoles with diatom frustules. Mnipellets were also found in faeces that were probably produced by copepods (j). Scale bars (a to d and $j !=25 \mu \mathrm{m}_{\mathrm{i}}$ (e to i) $=10 \mu \mathrm{m}$ 

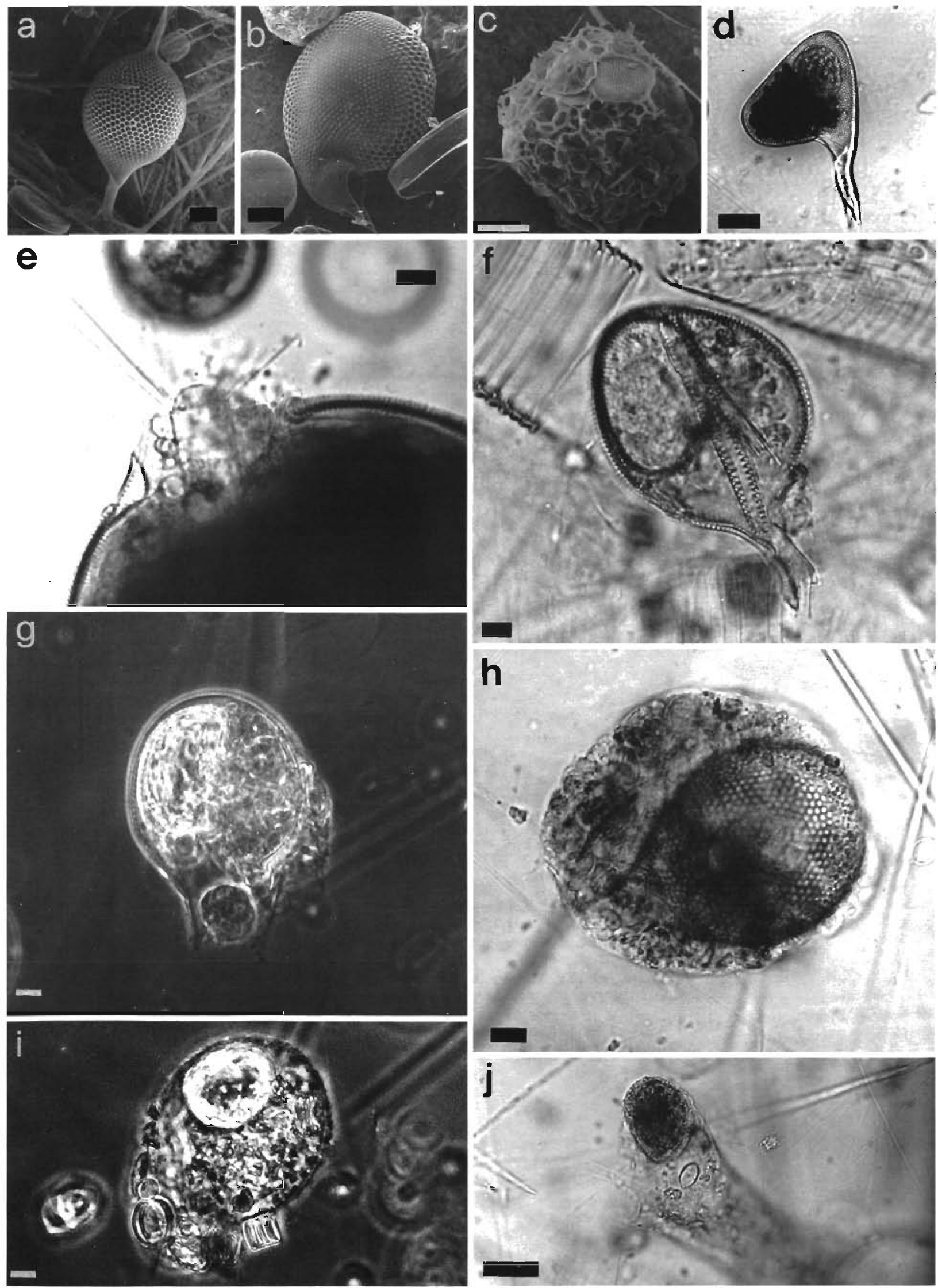
Table 1. Mean abundances of minipellets (total pellets $\mathrm{l}^{-1}$, averaged values from 0,40 and $100 \mathrm{~m}$ depth) and percentages of their contents (distinguished into 6 groups) from the 12 stations of the Scotia and Weddell Sea

\begin{tabular}{|c|c|c|c|c|c|c|c|c|c|c|c|c|}
\hline $\begin{array}{r}\text { Station: } \\
\text { No. of pellets examined: } \\
\text { Mean abundance }\left(1^{-1}\right) \text { : }\end{array}$ & $\begin{array}{c}143 \\
410 \\
1369\end{array}$ & $\begin{array}{c}147 \\
473 \\
1576\end{array}$ & $\begin{array}{c}153 \\
9 \\
30\end{array}$ & $\begin{array}{l}156 \\
28 \\
93\end{array}$ & $\begin{array}{l}157 \\
117 \\
389\end{array}$ & $\begin{array}{c}159 \\
96 \\
319\end{array}$ & $\begin{array}{l}160 \\
114 \\
380\end{array}$ & $\begin{array}{l}164 \\
12 \\
40\end{array}$ & $\begin{array}{l}169 \\
198 \\
660\end{array}$ & $\begin{array}{c}178 \\
30 \\
100\end{array}$ & $\begin{array}{c}190 \\
308 \\
1026\end{array}$ & $\begin{array}{c}207 \\
1761 \\
6081\end{array}$ \\
\hline & \multicolumn{12}{|c|}{ Minipellet contents (\%) } \\
\hline Nitzschia cylindrus ${ }^{d}$ & 0 & 3.4 & 43.3 & 0 & 16.2 & 41.7 & 35.0 & 0 & 13.2 & 20.0 & 3.9 & 38.5 \\
\hline Nitzschia sp. & 12.7 & 20.1 & 0 & 35.5 & 14.4 & 21.3 & 12.4 & 0 & 7.1 & 0 & 0 & 34.4 \\
\hline Thalassiosira sp. ${ }^{c}$ & 7.5 & 1.9 & 0 & 0 & 6.7 & 4.4 & 0 & 0 & 0 & 0 & 0 & 0.9 \\
\hline Thalassiosira + Nitzschiad & 19.4 & 5.3 & 0 & 0 & 3.3 & 6.6 & 0 & 0 & 0 & 0 & 0 & 10.4 \\
\hline Other taxa ${ }^{e}$ & 16.1 & 2.8 & 0 & 29.0 & 9.3 & 0 & 18.4 & 0 & 2.0 & 0 & 1.3 & 13.3 \\
\hline Unidentified' & 44.3 & 66.6 & 56.7 & 35.5 & 50.1 & 26.0 & 34.2 & 100.0 & 77.7 & 80.0 & 94.8 & 2.5 \\
\hline Total & 100 & 100 & 100 & 100 & 100 & 100 & 100 & 100 & 100 & 100 & 100 & 100 \\
\hline \multicolumn{13}{|c|}{$\begin{array}{l}\text { Nitzschia cylindrus and/or } N \text {. pseudonana } \\
\text { ' } N \text {. kerguelensis, N. rhombica, N. curta, N. lineola, } N \text {. closterium, } N \text {. prolongatoides, Nitzschia sp., Nitzschia fragments } \\
\text { 'Thalassiosira antarctica and/or T. gravida, Thalassiosira sp. } \\
\text { d. rhombica, N. lecontei, N. kerguelensis, N. cylindrus, N. curta, Nitzschia sp., Nitzschia fragments, T gracilis, T gravida, } \\
\text { T. lentiginosa. Thalassiosira sp. } \\
\text { "Distephanus speculum, Asteromphalus sp., diatom fragments, Bicosta spinifera, Corethron criophilum, Chaetoceros } \\
\text { neglectum, Chdeloceros sp., siliceous cyst, resting spore of Chaetoceros, Thalassiothrix sp., Chrysophycean cysts, Lepto- } \\
\text { cylindrus sp. and species of the genus Nitzschia and Thalassiosira } \\
\text { 'Unknown remains other than diatoms }\end{array}$} \\
\hline
\end{tabular}

Microscopic examination of water samples from the South Shetland Islands showed that heterotrophic flagellates $(>20 \mu \mathrm{m})$ had an average abundance of $3.4 \times 10^{3} \mathrm{l}^{-1}\left(\mathrm{SD}=4.5 \times 10^{3}, \mathrm{n}=21\right)$. Unarmoured dinoflagellates were observed with feeding vacuoles, which usually contained diatom frustules (Fig. 6E).

A total of 762 minipellets collected at the 12 stations in the SSIA were examined and the content determined (except $16.5 \%$ whose contents could not be identified). The food components found in minipellets were mostly frustules of the diatoms Porosira glacialis and Corethron criophilum. Other components included silicoflagellates (Distephanus speculum) and other unidentified, nondiatom remains (Table 2). Minipellets containing Porosira glacialis were the largest (mean volume of $8 \times$ $10^{5} \mu \mathrm{m}^{3}, \mathrm{SD}=4.3 \times 10^{5} \mu \mathrm{m}^{3}$ ) and dominated in abun-

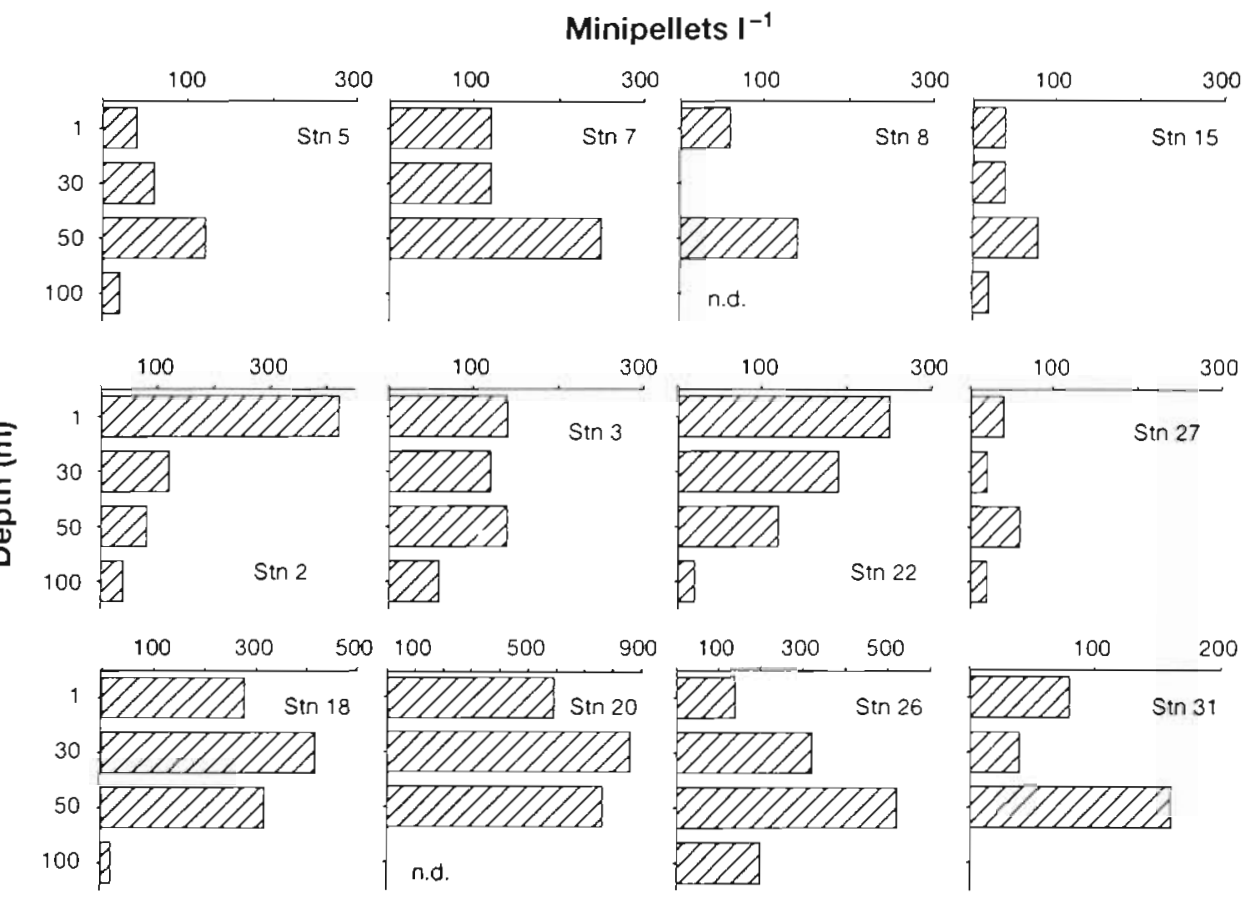

Fig. 5. Vertical distribution of minipellet abundance (no. of minipellets $1^{-1}$ ) in the Drake Passage (upper row), Bransfield Strait (middle row), and at the coastal stations (bottom row). n.d. = no data Note different scales of $x$-axis 

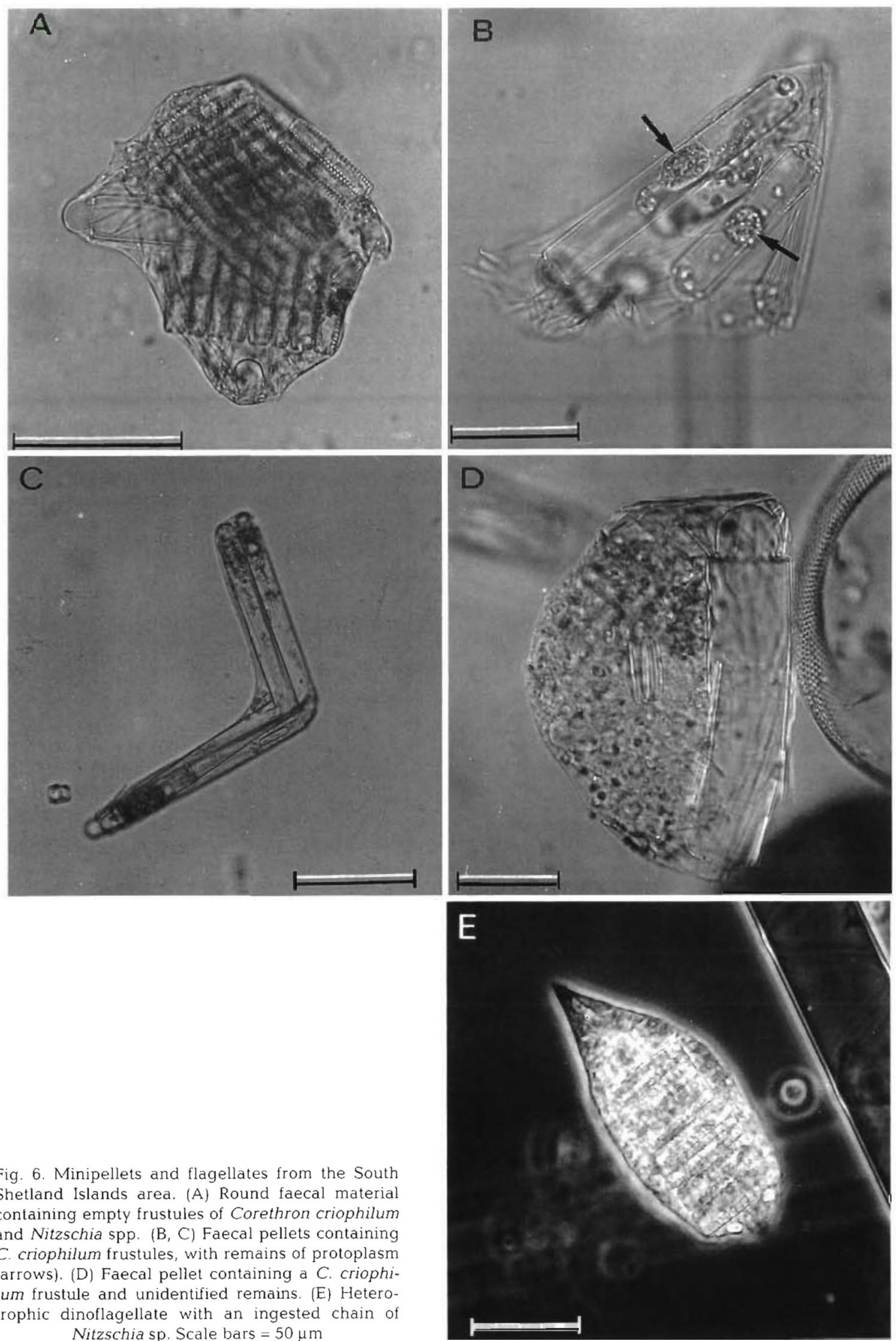

Fig. 6. Minipellets and flagellates from the South Shetland Islands area. (A) Round faecal material containing empty frustules of Corethron criophilum and Nitzschia spp. (B, C) Faecal pellets containing $C$ criophilum frustules, with remains of protoplasm (arrows). (D) Faecal pellet containing a C. criophilum frustule and unidentified remains. (E) Heterotrophic dinoflagellate with an ingested chain of Nitzschia sp. Scale bars $=50 \mu \mathrm{m}$ 
Table 2. Mean abundances of minipellets (total pellets $1^{-1}$, averaged values from $1,30,50$ and $100 \mathrm{~m}$ depth) and percentages of their contents (distinguished into 8 groups) from the 12 stations of the South Shetland Islands. The percentage of both total volume and numbers of minipellets for the 8 groups is also shown

\begin{tabular}{|c|c|c|c|c|c|c|c|c|c|c|c|c|c|c|}
\hline $\begin{array}{l}\text { Station: } \\
\text { No. of pellets examined: } \\
\text { Mean abundance }\left(1^{-1}\right) \text { : }\end{array}$ & $\begin{array}{c}5 \\
24 \\
60\end{array}$ & $\begin{array}{c}7 \\
48 \\
120\end{array}$ & $\begin{array}{c}8 \\
20 \\
50\end{array}$ & $\begin{array}{l}15 \\
18 \\
45\end{array}$ & $\begin{array}{c}2 \\
66 \\
165\end{array}$ & $\begin{array}{c}3 \\
46 \\
115\end{array}$ & $\begin{array}{l}22 \\
56 \\
140\end{array}$ & $\begin{array}{l}27 \\
14 \\
35\end{array}$ & $\begin{array}{c}18 \\
104 \\
260\end{array}$ & $\begin{array}{c}20 \\
220 \\
550\end{array}$ & $\begin{array}{c}26 \\
118 \\
295\end{array}$ & $\begin{array}{l}31 \\
28 \\
70\end{array}$ & $\begin{array}{l}\% \text { Total } \\
\text { volume }\end{array}$ & $\begin{array}{l}\% \text { Total } \\
\text { numbers }\end{array}$ \\
\hline \multicolumn{15}{|c|}{ Minipellet contents (\%) } \\
\hline Porosira glacialis $(\mathrm{Pg})$ & 41.7 & 45.8 & 0 & 0 & 18.2 & 4.4 & 0 & 0 & 57.7 & 41.8 & 40.7 & 0 & 66.70 & 32.28 \\
\hline Corethron criophilum (Cc) & 8.3 & 4.2 & 0 & 11.1 & 30.3 & 73.9 & 85.7 & 28.6 & 25.0 & 22.7 & 38.9 & 0 & 13.31 & 30.71 \\
\hline Thalassiosira sp. 1 & 25.0 & 16.7 & 0 & 11.1 & 6.1 & 4.4 & 0 & 28.6 & 13.5 & 10.0 & 3.4 & 0 & 2.73 & 8.66 \\
\hline Thalassiosira sp. 2 & 0 & 16.7 & 0 & 11.1 & 0 & 4.3 & 0 & 0 & 0 & 3.6 & 0 & 7.1 & 0.76 & 2.89 \\
\hline Nitzschia sp. & 16.7 & 0 & 0 & 0 & 9.1 & 0 & 0 & 0 & 0 & 3.6 & 3.4 & 0 & 0.46 & 2.89 \\
\hline$P g+C c+$ other taxa ${ }^{2}$ & 0 & 8.3 & 0 & 0 & 9.1 & 0 & 0 & 0 & 0 & 8.2 & 5.1 & 0 & 12.42 & 4.46 \\
\hline Other taxab & 0 & 0 & 0 & 11.1 & 0 & 0 & 0 & 0 & 1.9 & 1.9 & 3.4 & 0 & 0.61 & 1.57 \\
\hline Unidentified $^{c}$ & 8.3 & 8.3 & 100.0 & 55.6 & 27.3 & 13.0 & 14.3 & 42.8 & 1.9 & 8.2 & 5.1 & 92.9 & 3.01 & 16.54 \\
\hline Total & 100 & 100 & 100 & 100 & 100 & 100 & 100 & 100 & 100 & 100 & 100 & 100 & 100 & 100 \\
\hline
\end{tabular}

dance $(32.28 \%)$ and biomass $(66.7 \%)$. However, they were found in only 7 (out of 12) stations. The smallest pellets were those containing Nitzschia spp. (mean volume of $7 \times 10^{4} \mu \mathrm{m}^{3}, \mathrm{SD}=4 \times 10^{4} \mu \mathrm{m}^{3}$ ). Minipellets containing unidentified remains were on the average $8 \times 10^{4} \mu \mathrm{m}^{3}$ in size ( $\left.\mathrm{SD}=7.2 \times 10^{4} \mu \mathrm{m}^{3}\right)$. Even though these were relatively abundant and present in all stations, the contribution of these pellets to the total minipellet volume was minor $(3 \%)$.

Both the net-phytoplankton fraction of the sizefractionated chl a distribution (Fig. 7) and minipellet abundance (Fig. 5) were higher at the 'coastal-front' stations (except Str 31), when compared with the other 2 areas.

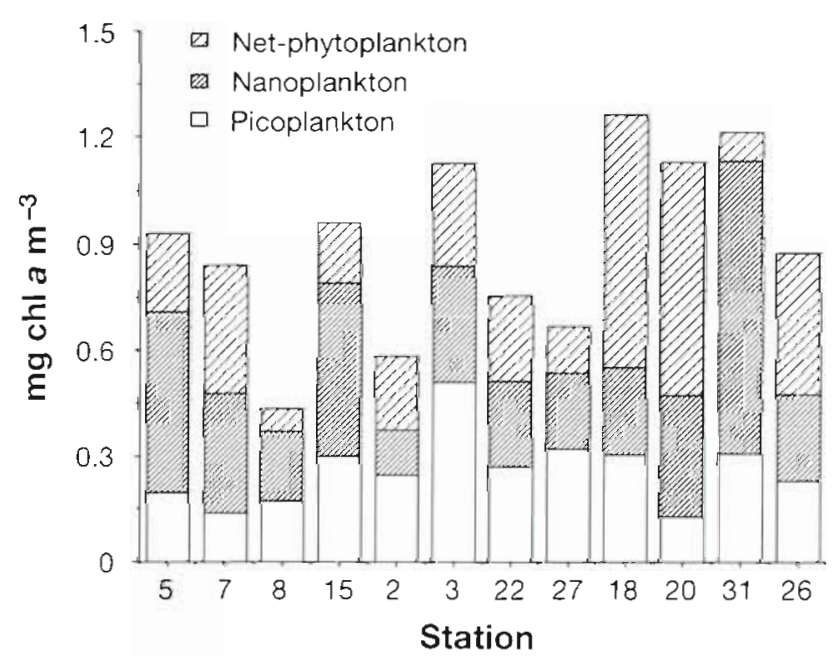

Fig. 7 Size-fractionated chlorophyll a distribution (mg chl a $\mathrm{m}^{-3}$ ) in the Drake Passage (Stns 5, 7. 8 \& 15), Bransfield Strait (Stns 2, 3, $22 \& 27$ ) and of the 'Coastal-front' stations (Stns 18, 20, 31 \& 26)
Correlation analysis between minipellet abundance and size-fractionated chl a indicated that minipellet abundance was positively correlated only with netphytoplankton $(r=0.72, n=23, p=0.0006)$.

\section{DISCUSSION}

\section{The Scotia and Weddell Seas}

Minipellets from these areas may be produced by different protistans, including flagellates, radiolarians, and other groups such as the nauplii of crustaceans. Ciliates seem to produce unconsolidated faeces which degrade rapidly due to microbial activity (Stoecker 1984, Antia 1991) and therefore are unlikely to significantly contribute to the observed faecal material. The importance of crustacean nauplii as potential minipellet producers is not clear. However, living calanoid nauplii (stages IV and V) with a food bolus in the digestive tract were often observed in fresh samples.

Phaeodarian radiolarians with the phaeodium full of minipellets (Fig. 4d) - or with partly released minipellets (Fig. $4 \mathrm{~g}$ ) - and unarmoured dinoflagellates with feeding vacuoles containing frustules of Nitzschia kerguelensis and Thalassiosira sp. were often observed in settling chambers during the counts. These findings support the idea that an important part of the recognizable minipellets in the water column originates from radiolarians and heterotrophic dinoflagellates. Faeces of small flagellates (euglenoids, chrysophytes) and ciliates were found in sea-ice samples from the Antarctic (Elbrächter 1991). However, since many of the small flagellate faeces were only about $1 \mu \mathrm{m}$ in size (Elbrächter 1991), most of these faeces were not included in the present study. 
Differences in the latitudinal distribution of minipellet abundance along the 49 and $47^{\circ} \mathrm{W}$ transects were found (Fig. 3). The $47^{\circ} \mathrm{W}$ transect crossed the shelf of the South Orkney Islands and water depth at Stn 169 was only $500 \mathrm{~m}$ in contrast to the other stations of the 47 and $49^{\circ} \mathrm{W}$ transects, which were more than $2000 \mathrm{~m}$ deep. The shelf induced changes in the water mass circulation which may generate a topographically-induced 'front' effect. Relatively high chl a concentrations - when compared with stations of similar latitude along the $49^{\circ} \mathrm{W}$ transects - were found at Stn 169 (integrated chl a concentrations for the upper $100 \mathrm{~m}$ of the water column at Stns 153, 156169 and 178 were $17.2,24.6,43.1$ and $26.4 \mathrm{mg} \mathrm{m}^{-2}$, respectively). In surface waters, when Stns 160, 164 and 169 are compared, the latter had the highest chl $a(0.124,0.498$ and $0.535 \mathrm{mg} \mathrm{m}^{-3}$, respectively) and $\mathrm{chl} b(0,0.016$ and $0.062 \mathrm{mg} \mathrm{m}^{-3}$, respectively) concentrations (A. Buma unpubl. data). In addition, a similar trend with higher abundances of krill faeces at Stn 169 than at ice-free stations was described (González 1992). Thus, results suggest that differences in autotrophic phytoplankton availability result in different faecal pellet production in both proto- and macro-zooplankton assemblages.

ln the northernmost stations of the Scotia Sea the net-phytoplankton was the dominant fraction (Jacques \& Panouse 1991). During the first $49^{\circ} \mathrm{W}$ transect a large phytoplankton bloom (up to $4 \mathrm{mg} c h l \mathrm{a} \mathrm{m}^{-3}$ ) dominated by small chain-forming diatoms occurred between 58 and $59^{\circ} \mathrm{S}$ in the WSC. At Stn $147\left(59^{\circ} \mathrm{S}\right)$ high numbers of minipellets $\left(108 \times 10^{6} \mathrm{~m}^{-2}\right)$ were found in the upper $100 \mathrm{~m}$ of the water column. Many of them (33\%) contained the same small diatoms abundant in the water column (mainly Nitzschia spp. and Thalassiosira spp.). The highest abundances of protozooplankton (unarmoured dinoflagellates, tintinnids and radiolarians) were reported in the same area (V. Alder pers. comm.), suggesting that their grazing pressure would have been high.

Despite the low chl a concentration recorded at Stn $143\left(0.23 \mathrm{mg} \mathrm{m}^{-3}\right)$, a large number of minipellets was found $\left(125 \times 10^{6} \mathrm{~m}^{-2}\right)$, probably related to diatom blooms that had been subsequently grazed down (the species composition in the water column remained dominated by small diatoms). It was pointed out by Jacques \& Panouse (1991) that in the Weddell-Scotia system, a change occurred during early summer from a new production-based ecosystem towards a regenerated system, progressing from the north to the south, partially associated with the retreat of the pack-ice.

In contrast, Stn 153 (ice-covered) was characterized by very low minipellet abundance $\left(3 \times 10^{6} \mathrm{~m}^{-2}\right)$ and chl a concentration $\left(0.12 \mathrm{mg} \mathrm{m}^{-3}\right)$. The species composition in the water column was dominated by small flagellates. Low numbers of Nitzschia cylindrus cells that were probably released from the ice were also present. Thus, low minipellet abundances were found associated with ice-covered stations. Highly variable concentrations of minipellets were found in open waters of the study area. Among other factors, patchy distribution of minipellet producers, continuous changes of the prevailing physical and chemical conditions (e.g. ice retreat, meandering polar front) and a relative poor knowledge of minipellet morphology contributed to obscuring minipellet potential origins and fates.

Population clearance rates of heterotrophic dinoflagellates and ciliates estimated for the SWS (Table 3) are in the range of 5 to $26 \mathrm{ml} \mathrm{l}^{-1} \mathrm{~h}^{-1}$ (using average abundances for the upper $100 \mathrm{~m}$ of the water column). These rates are in the range of values esti-

Table 3. Calculated clearance rates for populations of heterotrophic dinoflagellates and ciliates (tintinnids and aloricate) feeding on phytoplankton from the Scotia \& Weddell Sea

\begin{tabular}{|c|c|c|c|}
\hline Population & $\begin{array}{l}\text { Mean abundance }\left(1^{-1}\right) \text { within the } \\
\text { upper } 100 \mathrm{~m} \text { of the water column }\end{array}$ & $\begin{array}{l}\text { Clearance rate } \\
\left(\mu \mathrm{l} \text { ind }^{-1} \mathrm{~h}^{-1}\right)\end{array}$ & $\begin{array}{l}\text { Population clearance rate } \\
\qquad\left(\mathrm{ml} \mathrm{h}^{-1}\right)\end{array}$ \\
\hline $\begin{array}{l}\text { Armoured dinoflagellates } \\
(>20 \mu \mathrm{m})\end{array}$ & $141.0^{\mathrm{a}}$ & $1-28^{d}$ & $0.14-3.95$ \\
\hline $\begin{array}{l}\text { Unarmoured dinoflagellates } \\
(>20 \mu \mathrm{m})\end{array}$ & 4269.7 & $0.1-0.3^{e}$ & $0.43-1.28$ \\
\hline $\begin{array}{l}\text { Unarmoured dinoflagellates } \\
(<20 \mu \mathrm{m})\end{array}$ & $50000.0^{b}$ & $0.08-0.12^{b}$ & $4.00-6.00$ \\
\hline Tintinnids & $32.6^{c}$ & $1-65^{1}$ & $0.03-2.12$ \\
\hline Aloricate ciliates & 480 & $0.52-26^{9}$ & $0.25-12.48$ \\
\hline Range & & & $4.85-25.83$ \\
\hline \multicolumn{4}{|c|}{ 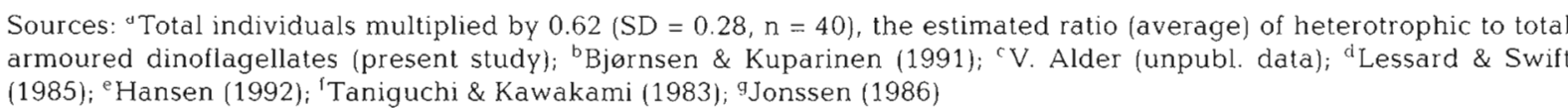 } \\
\hline
\end{tabular}


mated for other coastal and oceanic areas of the world (Lessard \& Swift 1985). Microcosm experiments conducted during the same cruise by Bjørnsen \& Kuparinen (1991) indicated that the phytoplankton grazing loss was almost equal to the heterotrophic dinoflagellate consumption rate. When comparing the flux of carbon via dinoflagellate consumption of phytoplankton with the transfer through bacteria and bacterivores the latter authors suggest that the latter pathway was insignificant.

Phaeodarian radiolarians from the upper $200 \mathrm{~m}$ of Antarctic waters can feed on a variety of particles ranging in size from bacteria to large protozoans (Gowing 1989). The abundant siliceous fragments in phaeodarian vacuoles suggest that phaeodarians from a variety of depths obtain their food mainly from particles and cells associated with detritus, i.e. faecal pellets and aggregates (Gowing 1989, Nöthig \& Gowing 1991). In the present study, however, radiolarians with partially ingested diatom frustules (see Fig. 4e) were found in net and water samples at Stns 157, 190 and 207 , indicating also a direct consumption of phytoplankton. Individuals with totally ingested diatoms (Fig. 4f) were also observed; however, consumption of undamaged diatoms through the ingestion of dinoflagellate minipellets or copepod pellets cannot be ruled out. Minipellets were found in pellets which were probably produced by copepods (Fig. 4j).

The present study focused on food particles with siliceous skeletons, in particular diatoms. Higher abundances of minipellets were coincident with higher diatom concentrations, indicating that diatom food results in greater production of minipellets. It appears that either flagellate populations were not heavily grazed or that the minipellets with unidentified remains (probably detritus or digested flagellates) were more easily destroyed/overlooked.

\section{South Shetland Islands}

Unarmoured dinoflagellates, many of them containing diatom frustules in feeding vacuoles, were often observed (Fig. 6E). The most abundant taxa in the water column were diatoms including Porosira glacialis, Corethron criophilum, Thalassiosira sp. and Nitzschia sp. and flagellates including Phaeocystis sp., Pyramimonas sp. and Cryptomonas sp. (author's unpubl. data). These taxa (except flagellates) were also the most frequent food items recognized in minipellets (Table 2). Protozoans from waters around the SSIA seem to predominantly feed on chain-forming diatoms with no evidence for species selection in this group. A relatively high Spearman rank correlation coefficient was found between the percentage of $C$. criophilum (with respect to total diatoms) in the water column and the percentage of minipellets containing only $C$. criophilum $(r=0.86)$. For $P$. glacialis the correlation was lower ( $r=0.59$ ) (Table 4). In the Bransfield Strait C. criophilum represented a large proportion of the total diatom population and its rise was paralleled by an increase in the proportion of minipellets with C. criophilum as a single item. A similar situation was observed at the 'coastal-front' stations (except Stn 31) for $P$. glacialis. In this area it is interesting to note that at Stn 20, C. criophilum and $P$. glacialis dominated at 1 and $50 \mathrm{~m}$ depths, respectively, and a similar trend was observed in the minipellets with these species as single food items (Table 4). In the Drake Passage both diatoms and minipellets with enclosed diatoms were scarce.

Rank correlation analysis between minipellet abundance and size-fractioned chl a indicated that minipellet abundance was positively correlated $(r=0.72$, $\mathrm{p}=0.0006$ ) only with net-phytoplankton, which was dominated by chain-forming diatoms. Heterotrophic dinoflagellates (>20 $\mu \mathrm{m}$ ) can be more abundant when diatoms dominate the phytoplankton (Smetacek 1981, Hansen 1991b), indicating that armoured and unarmoured dinoflagellates are able to respond numerically to diatom blooms (Hansen 1991b). Azam et al. (1983) assumed a linear size ratio of $10: 1$ between a predator and its prey within a pelagic food web. However, heterotrophic dinoflagellates seem to be an exception to this rule by preferring relatively large prey (Gaines \& Elbrächter 1987, Lessard 1991). Lessard (1991) pointed out that the few laboratory and field grazing estimates that exist would suggest that dinoflagellates could play a major role in the fate of diatom blooms'. Thus, evidence (including the predominance of minipellets larger than $1 \times 10^{5} \mu \mathrm{m}^{3}$ in volume) suggest that an important part of the minipellets may be produced by large $(>20 \mu \mathrm{m})$ heterotrophic dinoflagellates. Results do not allow a more definitive statement about the origin of the minipellets (unarmoured dinoflageliates, phaeodarian radiolarians or other potential producers). Some differences in the distribution of organisms and morphological characteristics of pellets tend to simplify the recognition of pellet origins. For example, it is well known that unarmoured dinoflagellates are more abundant in the upper $50 \mathrm{~m}$ of the water column. Also, in a very general sense, there are differences in unarmoured dinoflagellates and phaeodarian radiolarian pellets; the former are characterized more by a shape and size largely determined by the size and shape of the prey it is ingesting (i.e. Fig. 6A, C), and the latter more in line with minipellet original descriptions (Gowing \& Silver 1985). However, other distributional patterns and pellet characteristics augment the complexity of this problem, i.e. small 


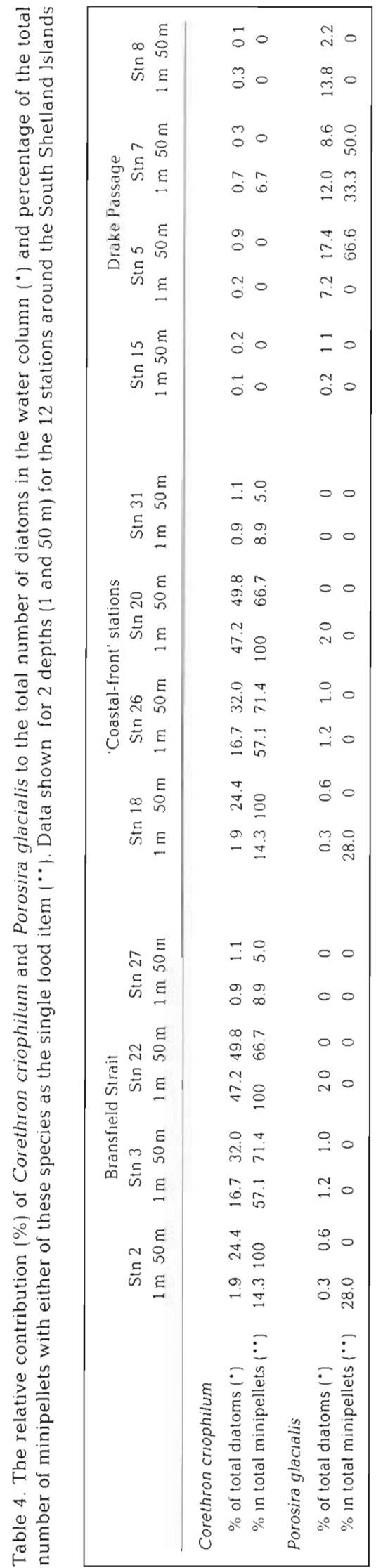

( 60 to $400 \mu \mathrm{m}$ in size) phaeodarian radiolarians which were supposed to be abundant only at depths of $100 \mathrm{~m}$ or greater (Gowing 1989) have been actually described with a vertical distribution pattern depending largely on the dominant species. A recent report indicated that phaeodarian radiolarians were more abundant in the upper $120 \mathrm{~m}$ of the water column in the Weddell Sea during winter (Nöthig \& Gowing 1991), which is in line with the information obtained during April-May 1992 in the same area (Table 5). The most abundant species, Challengeron bicorne, was mainly distributed in the upper $100 \mathrm{~m}$ of the water column, both in the MIZ (Stn 452) and at the ice-covered station (Stn 467). The other less abundant species were distributed at greater depths. Other aspects increasing the confusion between different origin of pellets were (1) the fact that phaeodarian radiolarians can ingest whole diatom frustules, and (2) the characteristics of the pellets produced by unarmoured dinoflagellate feeding on delicate (lacking of skeletons) prey are unknown, even though it is known that they can ingest such types of prey (see below).

An important fraction of the total minipellets (32 and $16 \%$ from the SWS and SSIA, respectively) contained unidentified food components. These minipellets were mainly round or oval, 5 to $50 \mu \mathrm{m}$ in diameter, greenish-yellowish and filled with a fine matrix conformed by small particles enclosed by a delicate boundary. These characteristics agree well with minipellets found inside phaeodarian radiolarians from net samples collected at 100 to $200 \mathrm{~m}$ depth, where detritus was the most probable food resource. However, phaeodarians could also be more abundant near the surface (Table 5), and feed on krill faecal pellets which were more abundant near the surface in the Weddell Sea (González 1992). At Stn 31 more than $90 \%$ of total minipellets contained unidentified food components, and there the phytoplankton was dominated by nanoplankton (Fig. 7), in particular by Pyramimonas sp. and Cryptomonas sp. and to a lesser extent by Phaeocystis sp. During enclosure experiments conducted in the Weddell Sea, cryptophytes were often found inside food vacuoles of the dinoflagellate Gymnodinium (Bjørnsen \& Kuparinen 1991); consumption of Phaeocystis pouchetii by Amphidinium sp. and Gymnodinium sp. has also been reported (Gaines \& Elbrächter 1987). Stn $8(100 \%$ minipellets with unidentified remains) was characterized by a low chl a concentration $(0.411$ $\mathrm{mg} \mathrm{m}^{-3}$ ), accounted for mainly by the pico- and nanoplankton size fractions (Fig. 7). Part of the unidentified remains may also be bacteria. At Stns 8 \& 31 maximum bacterial abundance (range 3 to $8 \times$ $10^{8} \mathrm{I}^{-1}$ ) and secondary production (range 0.55 to 1.9 $\mu \mathrm{g} \mathrm{Cl}^{-1} \mathrm{~d}^{-1}$ ) were recorded (Llanos et al. 1991). 
Table 5. Abundance (ind. $\mathrm{m}^{-3}$ ) of phaeodarian radiolarians in 5 depth intervals at 2 stations of the Weddell Sea during autumn 1992

\begin{tabular}{|c|c|c|c|c|c|}
\hline \multirow{2}{*}{ Species } & \multicolumn{5}{|c|}{ Sampling intervals (m) } \\
\hline & $0-90$ & $90-130$ & $130-200$ & $200-330$ & $330-1000$ \\
\hline \multicolumn{6}{|c|}{ Stn $452\left(68^{\circ} 00.8^{\prime} \mathrm{S}, 12^{\circ} 04.1^{\prime} \mathrm{W}\right), 26 \operatorname{Apr} 1992$} \\
\hline Protocystis micropelecus & 11 & 17 & 39 & 29 & 13 \\
\hline Protocystis tridens/acornis & 17 & 22 & 56 & 53 & 14 \\
\hline Challengeron bicorne & 1624 & 130 & 44 & 20 & 3 \\
\hline Cycladophora bicornis & 6 & 9 & 4 & 1 & 8 \\
\hline Total & 1658 & 178 & 143 & 103 & 38 \\
\hline \multicolumn{6}{|c|}{ Stn 467 ( $70^{\circ} 18.5^{\prime} \mathrm{S}, 12^{\circ} 03.3^{\prime} \mathrm{W}$ ), 1 May 1992} \\
\hline Protocystis micropelecus & 3 & 3 & 13 & 37 & 5 \\
\hline Protocystis tridens/acornis & 3 & 3 & 4 & 8 & 0.4 \\
\hline Challengeron bicorne & 261 & 150 & 1 & 3 & 0.8 \\
\hline Protocystis harstoni & 0 & 0 & 2 & 3 & 7 \\
\hline Cycladophora bicornis & 0 & 0 & 0 & 0 & 2 \\
\hline Total & 267 & 156 & 20 & 51 & 15.2 \\
\hline
\end{tabular}

\section{Fate of minipellets in Antarctic waters}

The fate of minipellets in the surface and deep water is still an open question. Some of them can be transported in dense gelatinous aggregates to depth since small phaeodarian faecal pellets were found at $4500 \mathrm{~m}$ depth in the northeast Atlantic (Riemann 1989). Small faeces have been collected below $1000 \mathrm{~m}$ depth in the Weddell Sea, suggesting that they were a transport vehicle of intact diatom frustules to depth (Nöthig \& Bodungen 1989). However, these could also be produced by deep-living radiolarian populations (M. M. Gowing pers. comm.).

Minipellets in the SWS and SSIA were probably produced and consumed/disintegrated near the surface, since abundances decreased from $50 \mathrm{~m}$ to $100 \mathrm{~m}$ depth (Figs. 2 \& 5).

The microbial network is regarded as a characteristic component of the Antarctic pelagial (Smetacek et al. 1990), where protozoans act as a link coupling picoand nanoplankton production to higher trophic levels (Hewes et al. 1985). For example, phaeodarians (able to feed on particles ranging from bacteria to large protozoans) can be consumed by Salpa thompsoni in the Weddell Sea and Antarctic Peninsula (Gowing 1989), thus providing a link between the microbial food-web and macrozooplankton. In the Southern Ocean, more attention has been devoted to the krill grazing impact on phytoplankton populations. Comparing faecal material produced by protistans and krill, it is evident that in terms of volume, minipellets are negligible ( 3 to 5 orders of magnitude smaller , and usually they are either missing from net samples (>100 $\mu \mathrm{m}$ mesh size), or overlooked in water samples. However, minipellets counted during this study were on average 5 orders of magnitude more abundant than krill faeces $\left(489000 \mathrm{~m}^{-3}\right.$ and $8.7 \mathrm{~m}^{-3}$, respectively). In terms of food contents, diatom frustules were the dominant item in both krill (mainly at the form of finely shredded debris; González 1992) and protistan (mainly undamaged frustules) pellets. Since small $(<20 \mu \mathrm{m})$ unarmoured dinoflagellates dominated when nanoflagellates were abundant (Bjørnsen \& Kuparinen 1991), and the large species (>20 $\mu \mathrm{m}$ ) dominated when diatoms were abundant (Hansen 1991b), it seems that many of the minipellets recognized during the present study belong to the large heterotrophic dinoflagellates, and that they compete with krill for large prey (i.e. chain-forming diatoms). These findings emphasize the role of the protistans as voracious herbivores in the microbial network.

Acknowledgements. I am grateful for the highly professional assistance provided by captains and crews of RV 'Polarstern' and RV 'Capitán Alcazar' Data presented here were collected during the second leg of the European Polarstern Study (EPOS) sponsored by the European Science Foundation and the Alfred Wegener Institute for Polar and Marine Research, as well as during the XXVI Antarctic Chilean Expedition, sponsored by the Antarctic Chilean Institute (INACH). B. Iriarte and the AML team greatly helped in the collection of samples. This study benefited from discussions with and improvements to the manuscript by V. Alder, F. Brandini, K. Lochte, E.-M. Nöthig, U. Riebesell, D. Thomas and 3 anonymous reviewers. I am very grateful to Drs Marcia Gowing (Univ. of California) and V. Smetacek (AWI) who made major comments and contributions to improve the manuscript. Publication number 611 of the Alfred Wegener Institute for Polar and Marine Research.

\section{LITERATURE CITED}

Amos, A. F. (1987). RACER: physical oceanography of the western Bransfield Strait. Antarct. J. U.S. 22: 137-140

Antia, A. N. (1991). Microzooplankton in the pelagic fond web of the East Greenland Sea and its role in sedimentation processes. Ber Sonderforschungsbereich, Univ. Kiel 33: $1-1.09$ 
Azam, F., Fenchel, T., Field, J. G., Gray, J. S., Meyer-Reil, L. A., Thingstad, F. (1983). The ecological role of watercolumn microbes in the sea. Mar Ecol. Prog. Ser. 10: $257-263$

Bjornsen, P. K., Kuparinen, J. (1991). Growth and herbivory by heterotrophic dinoflagellates in the Southern Ocean, studied by microcosm experiments. Mar. Biol. 109: $397-405$

Buck, K. R., Bolt, P. A., Garrison, D. L. (1990). Phagotrophy and fecal pellet production by an athecate dinoflagellate in Antarctic sea ice. Mar. Ecol. Prog. Ser. 60: 75-84

Elbrächter, M. (1991). Faeces production by dinoflagellates and other small flagellates. Mar. microb. Food Webs 5: $189-204$

Gaines, G., Elbrächter, M. (1987). Heterotrophic nutrition. In: Taylor, F. J. R. (ed.) The biology of dinoflagellates. Blackwell, Oxford, p. 224-268

Garrison, D. L., Gowing, M. M. (in press). Protozooplankton. In: Friedmann, E. I. (ed.) Antarctic microbiology, WileyLiss, New York

González, H. (1992). The distribution and abundance of krill faecal material and oval pellets in the Scotia and Weddell Seas (Antarctica) and their role in particle flux. Polar Biol. 12: $81-91$

González, H., Pantoja, S., Iriarte, J. L., Bernal, P. A. (1989). Winter-spring variability of size-fractioned autotrophic biomass in Concepción Bay, Chile. J Plankton Res. 11: $1157-1167$

Gowing, M. M. (1989). Abundance and feeding ecology of Antarctic phaeodarian radiolarians. Mar. Biol. 103: $107-118$

Gowing, M. M., Coale, S. L. (1988). Phaeodarians in the iceedge zone of the Weddell Sea and in the Antarctic Peninsula region. Antarct. J. U.S. 23: 121-123

Gowing, M. M., Coale, S. L. (1989). Fluxes of living radiolarians and their skeletons along a northeast Pacific transect from coastal upwelling to open ocean waters. Deep Sea Res. 36: 561-576

Gowing, M. M., Silver, M. W. (1985). Minipellets: a new and abundant size class of marine faecal pellets. J. mar. Res. 43: $395-418$

Hansen, P. J. (1991a). Dinophysis - a planktonic dinoflagellate genus which can act both as a prey and a predator of a ciliate. Mar. Ecol. Prog. Ser. 69: 201-204

Hansen, P. J. (1991b). Quantitative importance and trophic role of heterotrophic dinoflagellates in a coastal pelagial food web. Mar. Ecol. Prog. Ser 73: 253-261

Hansen, P. J. (1992). Prey size selection, feeding rates and growth dynamics of heterotrophic dinoflagellates with special emphasis on Gyrodinium spirale. Mar. Biol. 114: $327-334$

Hasle, G. R. (1964). Nitzschia and Fragillariopsis species studied in the light and electron microscopes. I. Some marine species of the groups Nitzschiella and Lanceolatae. Skr. Norske. VidenskAkad. Oslo 16: 1-48

Hasle, G. R. (1965a). Nitzschia and Fragillariopsis species studied in the light and electron microscopes. II. The group Pseudonitzschia. Skr. Norske. VidenskAkad. Oslo 18: $1-45$

Hasle, G. R. (1965b). Nitzschia and Fragillariopsis species studied in the light and electron microscopes. III. The genus Fragillariopsis. Skr. Norske. VidenskAkad Oslo 16 : $1-48$

Hasle, G. R., Fryxell, G. A. (1970). Diatoms: cleaning and mounting for light and electron microscopy. Am. Microb. Soc. Trans. 89: 469-474

Hempel, I., Schalk., P. H., Smetacek, V. (1989). The Expedi- tion Antarktis VII/3 (EPOS Leg 2) of RV 'Polarstern' in 1988/89. Ber. Polarforsch. 65: 1-199

Hewes, C. D., Holm-Hansen, O., Sakshaug, E. (1985). Alternate carbon pathways at lower trophic levels in the Antarctic food web. In: Siegfried, W. R., Condy, P. R., Laws, R. M. (eds.) Antarctic nutrient cycles and food webs. Springer-Verlag, Berlin, p. 277-283

Jacques, J., Panouse, M. (1991). Biomass and composition of size fractionated phytoplankton in the Weddell-Scotia Confluence area. Polar Biol. 11:315-328

Jacobson, D. M., Anderson, D. M. (1986). Thecate heterotrophic dinoflagellates: feeding behavior and mechanisms. J. Phycol. 22: 249-258

Jonsson, P. R. (1986). Particle size selection, feeding rates and growth dynamics of marine planktonic oligotrichous ciliates (Ciliophora: Oligotrichina). Mar. Ecol Prog. Ser 33: $265-277$

Lessard, E. J. (1991). The trophic role of heterotrophic dinoflagellates in diverse marine environments. Mar. microb. Food Webs 5: 49-58

Lessard, E. J., Swift, E. (1985). Species-specific grazing rates of heterotrophic dinoflagellates in oceanic waters, measured with a dual-label radioisotope technique. Mar Biol. 87: 289-296

Llanos, A., Acevedo, A., Troncoso, V. A., González, H., Marín S., Iriarte, J. L., Bernal, P. A. (1991). Abundancia y producción secundaria bacteriana en el área de las Islas Shetland del Sur. Ser. Cient. INACH 41: 55-63

Medlin, L. K., Priddle, J. (1990). Polar marine diatoms. British Antarctic Survey, Cambridge, p. 1-214

Morley, J. J., Stepien, J. C. (1985). Antarctic Radiolaria in late winter/early spring Weddell Sea waters. Micropaleontology $31: 365-371$

Nöthig, E.-M., Bodungen, B. v. (1989). Occurrence and vertical flux of faecal pellets of probably protozoan origin in the southeastern Weddell Sea (Antarctica). Mar. Ecol. Prog. Ser. 56: 281-189

Nöthig, E.-M., Gowing, M. M. (1991). Late winter abundance and distribution of phaeodarian radiolarians, other large protozooplankton and copepod nauplii in the Weddell Sea, Antarctica. Mar. Biol. 111: 473-484

Popofsky, A. (1908). Die Radiolarien der Antarktis (mit Ausnahme der Tripyleen). Deutsche Südpolar-Expedition 10 . Zoologie 2, Berlin, p. 183-305

Porter, K. G., Feig, Y. S. (1980). The use of DAPI for identifying and counting aquatic microflora. Limnol Oceanogr. 25: $943-948$

Priddle, J., Fryxell, G. A. (1985). Handbook of the common plankton diatoms of the Southern Ocean: Centrales except the genus Thalassiosira. British Antarctic Survey, Cambridge, p. 1-159

Riemann, F. (1989). Gelatinous phytoplankton detritus aggregates on the Atlantic deep-sea bed. Mar. Biol. 100: 533-539

Schnepf, E., Elbrächter, M. (1992). Nutritional strategies in dinoflagellates. A review with emphasis on cell biological aspects. Eur. J. Protistol. 28: 3-24

Schröder, O. (1912). Die tripyleen Radiolarien (Phaeodarien) der Deutschen Südpolar-Expedition 1901-1903. Deutsche Südpolar-Expedition 14, Zoologie 6, Berlin, p. 114-215

Smetacek, V. (1981). The annual cycle of protozooplankton in the Kiel Bight. Mar. Biol. 63: 1-11

Smetacek, V., Scharek, R., Nöthig, E.-M. (1990). Seasonal and regional variation in the pelagial and its relationship to the life history cycle of krill. In: Kerry, K. R., Hempel, G. (eds.) Antarctic ecosystems. Ecological change and conservation. Springer-Verlag, Berlin, p. 103-114

Stoecker, D. K. (1984). Particle production by marine ciliates. 
Limnol. Oceanogr. 29: 930-940

Taniguchi, A., Kawakami, R. (1983). Growth rates of ciliate

Eutintinnus lususundae and Farnlla taraikaensis observed in the laboratory culture experments. Bull. Plankton Soc. Japan 30: 33-40

This article was submitted to the editor
Utermöhl, H. (1958). Vervollkommnung der quantitativen Phytoplankton-Methodik. Mitt. internat. Verein. theor. angew. Limnol. 9:1-38

Zar, J. H. (1984). Biostatistical analysis, 2nd edn. Prentice Hall Inc., Englewood Cliffs

Manuscript first received: June 23,1992

Revised version accepted: December 1, 1992 